\title{
Civil Society Groups (CSGs) and the Democratisation Process in Nigeria, 1960-2007
}

\author{
Adewunmi James Falode, PhD \\ Department of History and International Studies, Faculty of Arts, Lagos State University, \\ PMB 0001, LASU Post Office, Lagos, Nigeria \\ E-mail address: adewunmi.falode@lasu.edu.ng
}

\begin{abstract}
Keywords: Democratisation, Civil Society Groups, Nigeria, Military Rule, Democracy, Conceptual mechanism.
\end{abstract}

\begin{abstract}
This paper analyses the significant role the civil society groups (CSGs) played in the democratisation process in Nigeria between 1960 and 2007. The paper discovers that the CSGs made use of the conceptual mechanism in the democratisation process of Nigeria. The conceptual mechanism allowed the CSGs to inject such important concepts as accountability, rule of law, democracy, transparency, human rights and due process into the democratization process between 1960 and 2007. These concepts were used to tackle some of the major democratization challenges, such as corruption, religious crisis and governance that confronted Nigeria between 1960 and 2007. By using the historical methodology, the paper analyses the crucial role the CSGs played in both the civilian and military administrations thatgoverned Nigeria between 1960 and 2007. The central thrust of the paper is to show how the CSGs contributed to the enthronement of democracy and democratic practices in Nigeria.
\end{abstract}

\section{Introduction}

For much of its existence, Nigeria was governed by the military. From 1960 to 2007, a total of forty-seven years, the military ruled for twenty-nine years. The remaining eighteen years were under civilian rule. What this means is that democratization had a short gestation period in Nigeria. At independence in 1960, the country was welcomed into the comity of democratic nations because the major key policymakers were all democratically elected. The federal election that ushered in the first republic was seen as a step in the right direction for the country. It was assumed by local and international observers that with time, the democratization process will allow Nigeria to transmute from procedural to substantive democracy [1]. This was not to be. By 1966, because of the first military coup in the country's history, the democratization process was truncated. The long military interregnum that occurred from 1966 to 1979 and 1983 to 1998 dealt a severe blow to the country's democratization process. Such basic democratic rights as representative government, enfranchisement, political parties' formation and association and human rights were undermined during military rule. The democratization process did not fare any better under civilian administration from 1960 to 1966,1979 to 1983 and 1999 to 2007. Key democratic tenets and practices that would have deepened the country's democracy, such as human rights, transparency and accountability and due process, were not allowed to flourish. The non-existence of a functional and effective opposition political party was also a crucial factor that militated against the deepening of democracy in Nigeria. It was the failure of the Federal Government of Nigeria (FGN) to deepen the country's democracy that provided the opportunity for the Civil Society Groups (CSGs) to inject the needed catalyst into Nigeria's democratization process between 1960 and 2007.

Four major mechanisms were used in Nigeria between 1960 and 2007 to tackle the challenges of democratization [2]. These are the institutional, praetorian, constitutional and conceptual mechanisms. Constitutional mechanism simply means the use of specific provisions in the Nigerian constitution to deepen the democratization process. Institutional mechanism means the creation and use of structures and organisations that can help in the integration of the Nigerian society. Conceptual mechanism is the use of targeted ideas, norms and intellection in the democratization process. While, praetorian mechanism is the use of military edicts and decrees in the 
democratization process. Institutional, constitutional and praetorian mechanisms are what the (FGN) used between 1960 and 2007 in the democratization process. While the conceptual mechanism was the tool the CSGs used in the democratization process. The use of these mechanisms was noticeable in the country's democratization process between 1967 and 2007. For instance, Olusegun Obasanjo's administration made use of the institutional mechanism to tackle specific challenges of democratization between 1999 and 2007. This was the rationale behind the formation of the Economic and Financial Crimes Commission (EFCC) in 2003. It was an institutional response meant to tackle the challenge of corruption [3]. General Yakubu Gowon's establishment of the National Youth Service Corps (NYSC) in 1973 was another institutional program meant to help the democratization process in Nigeria NYSC was meantto foster cross- and inter-cultural tolerance and cooperation among the youths from different ethnic backgrounds in the Nigerian state. Other administrations adopted the constitutional mechanism to tackle specific aspects of Nigeria's democratization challenges.

A particular challenge that confronted Nigeria at independence was the search for a viable democratic-cum-political system. Due to Nigeria's cultural heterogeneity and ethnic diversity, federalism was adopted at independence. The different administrations saw the Nigerian constitution as an important avenue through which some of the challenges of a viable political structure and governance could be resolved. Hence, the FGN felt compelled to amend and alter the various Nigerian constitutions and insert provisions that were designed to make Nigeria politically and socially cohesive. This is the rationale behind the insertion of the federal character principle and principle of fiscal federalism in the 1979 Nigerian Constitution by the General Olusegun Obasanjo regime in 1979 [4, 5]. This insertion was done, it must be noted, to ensure that all the ethnic groups are represented at the centre and to also ensure the equitable distribution of federal resources.

Praetorian mechanism was the favoured tool of the different military administrations that ruled Nigeria from 1967 to 1999. This tool involved the use of decrees and edicts to tackle Nigeria's nation-building challenges. For example, Major General Aguiyi Ironsi used decrees 33 and 34 of 1966 to turn Nigeria into a unitary state [6]. This was done to tackle the problem of unity in the country's democratization process. General Yakubu Gowon used the Enterprise Promotion decree No. 4 of 1972 to tackle the challenge of economic insufficiency [7]. And, General Ibrahim Babangida used military decree to establish Mass Mobilization for Self Reliance, Economic Recovery and Social Justice (MAMSER) in 1987 [8]. MAMSER was designed to make Nigeria socio-economically and politically viable. However, since this paper is about the role of the CSGs in the democratization process, the emphasis will be on how these groups used the conceptual mechanism to deepen Nigeria's democracy between 1960 and 2007.

\section{Conceptual Clarifications}

\section{(i) Conceptual mechanism}

This was the favoured tool of the CSGs in the nation-building process. Conceptual mechanism involves the use of targeted ideas, precepts, norms, intellection and principles in Nigeria's democratization process. Such concepts include transparency, governance, accountability and rule of law. Since the CSGs is not a government parastatal, it had to inject such concepts into the nationbuilding process in a complementary manner. That is to say, the CSGs had to act as the fourth estate in the Nigerian political space and 'coerce', and at the same time cajole the FGN to adopt these concepts. The CSGs modus operandi within the Nigerian socio-political space was to mobilize the civil society to embark on industrial strikes; carry-out extensive mobilization campaigns aimed at sensitization; and hold workshops and seminars aimed towards tackling specific national issues.Forexample, the National Democratic Coalition (NADECO) used the concepts of accountability and democracy to spur the democratization process in Nigeria during military rule in the 1990s. NADECO achieved this through a mass sensitisation campaign. Various workshops and seminars were held across the country. The mass media was effectively used to disseminate the 
ideas and significance of such concepts. Pressure was then brought to bear on the FGN who was forced to include some of the principles in the country's democratic process.

(ii) Civil Society Groups (CSGs)

Civil Society Groups (CSGs) refer to the set of institutions and organizations that inter-phase between the state, business world, and the family [9]. Larry Diamond defines CSGs as organized social life that is open, voluntary, self-generating, autonomous from the state and bound by a legal order or set of shared rules [10]. CSGs' importance, according to Keane John, stems from the realization that a stable democracy rests not only on proper functioning elections and institutions but also on civic qualities in society [11]. Civil society is the arena outside of the family, the state and the market where people associate to advance common interests [12]. Osaghae has identified three key elements as important in the definition or conceptualization of CSGs [13]: autonomy fromthe state, public character (setting a normative order for the state) and furtherance of a common good. Broadly speaking, CSGs include non-governmental organizations (NGOs), Private Voluntary Organization, Community Based Organizations (CBOs), civic clubs, trade unions, gender groups, cultural and religious groups,charities, social and sports clubs, cooperatives, environmental groups, professional associations, academic and policy institutions, consumer organizations and the media. CSGs commonly embrace a diversity of spaces, actors and institutional forms varying in their degree of formality, autonomy and power. All these types have existed in Nigeria at one time or the other.

\section{(iii) Democratization}

Democracy is a system of government that embodies in a variety of institutions and mechanisms, the ideal of political power based on the will of the people [14]. Democracy is about the institutionalization of people power [15]. People power is institutionalized through civil freedoms. These freedoms, such as human rights and enfranchisement, entitle people to govern their lives based on personal preferences in public and private spheres. Democratization is the process by which this happens. It is a process which leads to a more open, more participatory, less authoritarian society. Democratization could also be taken to be the movement of a non-democratic regime to a procedural democracy and eventually a substantive democracy. This transformation can take place in either the first government in a newly independent country or by replacing an authoritarian system in an older one. For example, Nigeria's democracy effectively took root in 1999. One can refer to this as the procedural phase. It is to be noted however, that democratic transition did not go beyond this phase in Nigeria between 1960 and 2007.

Democratization can further be understood in three different ways. First, it is the introduction of democracy in a non-democratic regime. Second, it is the deepening of the democratic qualities of given democracies. Thirdly, it involves the question of the survival of democracy. Using Welzel's explanation of democratization, one can assert that Nigeria's democracy has only gone through the first stage. The first stage marked the dawn of the Fourth Republic in 1999. As will be pointed out in the course of the analysis, the country failed to advance to the last two stages of democratization. Historically, there are three waves or phases of democratization [16]. The first phase started in the nineteenth century and came to an end by the end of the Second World War in 1945. The second wave came up as a consequence of the end of the Second World War. The victory of the allies in the war led to the breakup of European colonial empires in Asia, Africa, Middle East and the Carribean. Finally, the late 1970s saw the beginning of the third wave of democratization that started in southern Europe, spread through Latin America and Asia and accelerated with the collapse of the USSR between 1989 and 1991.

\section{CSGS and the Democratization Process in Nigeria: A Background}

Conceptual mechanism was the preference of civil society groups (CSGs) in resolving Nigeria's democratization challenges between 1960 and 2007. By its structure, CSGs include a wide range of institutions including non-governmental organizations, faith based institutions, community groups, 
professional associations, pro-democracy groups, trade unions, media organizations and research institutes [17]. In contrast to the vertical approach adopted by the FGN, CSGs adopted the horizontal approach in the country's democratization process. This approach fostered interactions and the exchange and dissemination of ideas across the socio-cultural and political spectrum of Nigeria. The approach further afforded the CSGs the opportunity to play pivotal roles in Nigeria's democratization process during the period.

The CSGs that operated in Nigeria during the period under study are of two types. There are those that were involved in the democratization process from within the country; and those whose efforts were channeled from outside the country. Some of the CSGs that played prominent roles in the period under consideration include Civil Liberties Organization (CLO) formed in 1987; Campaign for Democracy (CD) formed in 1991 [18]; and National Democratic Coalition (NADECO) formed in 1994 [19]. All these are from within the country. The National Liberation Council of Nigeria (NALICON), formed in 1995, and United Democratic Front for Nigeria (UDFN), formed in 1996, are two examples of those from outside the country [20,21]. The CSGs injected targeted concepts and ideas such as democracy, human rights, transparency, accountability and rule of law into the Nigerian democratization process.

Several scholars, including social scientists, have treated the incursion of CSGs into the Nigerian political and social spheres as a recent phenomenon. But, in actual fact, CSGs such as trade unions, student movements, town or village unions, community associations, religious organizations have existed in Nigeria as far back as the colonial period [22]. The era of British imperial rule in Nigeria witnessed the beginning of CSGs in Nigeria. The CSGs not only helped in organizing revolts against specific colonial policy, but also engendered social and societal transformation. For example, the 1935 Cooperative Societies Ordinance, promulgated in 1935 during the heyday of colonial rule, promoted CSGs activities in Nigeria. Moreover, CSGs played significant role in ending colonial rule in Nigeria. The Aba and Abeokuta women struggle and the Enugu Coal Miners' strike are two good examples. The activities of indigenous press, such as the West African Pilot, owned by Nnamdi Azikiwe and Lagos Daily News, owned by Herbert Macaulay, further aided the decolonization process. It must, however, be noted that CSGs activities in the colonial period were aimed at forcing the British to repeal specific policies considered by them to be obnoxious; and at the same time force them to allow Nigerians to participate more in the political process within the country.

Post-independent Nigeria witnessed the active contribution of CSGs to the democratization process in the country. Following the collapse of civilian rule in 1966 and at the peak of military rule in the 1980s, many politically oriented CSGs emerged on the Nigerian landscape. Scholars generally agree that the weakening of the Nigerian economy in the 1980s, executive excesses and abuses, the state's repressive policies and unbridled capital accumulation by the elites contributed greatly to the active surge of CSGs movements in Nigeria between 1980 and 2007. Three important phases marked the development of CSGs in Nigeria up to 2007 [23]. The first phase was informed by a national liberation struggle. Colonial rule, with the repressive policies it engendered, led to the creation of nationalist movements that fought the British for Nigeria's independence. However, with the end of colonial rule in 1960, these early CSGs faded from the national arena. This is because of the fact that there was no common cause to galvanize them into action. Also, since these early CSGs came up as a result of reaction to British colonial policies, the attainment of independence meant that their services were no longer needed. For instance, Nigerian prime minister at independence, Sir Tafawa Balewa, did not see the CSGs as valuable partners in the creation of a viable and functional Nigeria. And thus, the enabling environment for their activities was never created.

The second phase came about as a result of the failed economic policies and extra-juridical and extra-constitutional leanings of the Ibrahim Babangida and Sani Abacha military juntas. Protests and demonstrations against the SAP of Babangida galvanized and mobilized CSGs activities in Nigeria. Sani Abacha's 'undemocratic' utterances and credentials were important catalyst for an upsurge in the activities of CSGs during this phase. Issues that dominated this phase were those of 
democracy, human rights, constitutionalism and accountability. The third phase, which was in the democratic era, was characterized by issues such as governance, electoral laws, tenure elongation, sovereign national conference and transparency. Obasanjo's excesses, such as his disregard for the rule of law, lack of transparency in governance, and his desire to extend his tenure, injected the needed catalyst into the CSGs' movement in Nigeria. During Obasanjo's administration, CSGs became a force to be reckoned with in the Nigerian civil and political arena.

Significantly, as state institutions deteriorated, more and more CSGs emerged. Indeed, it was during this period that the largest number of CSGs was registered in Nigeria [24]. Most of these CSGs came into existence to tackle specific areas of concern within the country's socio-political milieu. For example, the leading CSGs formed specifically to target corruption-related issues in Nigeria include: Transparency International in Nigeria (TIN), Integrity and Zero-Corruption Coalition (ZCC). Those formed to tackle issues of governance such as accountability, rule of law and transparency includes: Nigeria Bar Association (NBA), Centre for Democracy and Development (CDD), and the Nigerian Labour Congress (NLC). Those that tackle specific cases of human rights violation include: Civil Liberties Organisation (CLO), Committee for the Defence of Human Rights (CDHR) and Human Rights Law Services (Huri-Laws).

In extraordinary circumstances, issues that sometimes touched on the corporate existence of the nation had a way of bringing about a coalescence of these different CSGs. That is, the activities and concerns of these CSGs sometimes converge. This was always in reaction to specific policies of the state that the CSGs believed no single organization can handle. This phenomenon was noticeable during the regimes of both Babangida and Abacha. The annulment of the June 12, 1993 presidential election and the consequent convergence of interests this generated among the CSGs made them to form National Democratic Coalition (NADECO). Similarly, Abacha's desire to transmute into a civilian president in 1998, and the regime's intolerance of dissent, united the CSGs against the regime. This was the reason behind the formation of the United Action for Democracy (UAD).

Between 1980 and 2007, the CSGs played three important roles in Nigeria's democratization process. Firstly, it galvanized the masses against unpopular economic policies within the SAP framework. Secondly, a plethora of CSGs that comprised grassroots, community-based associations, and faith-based organizations emerged to provide assistance to their members and non-members in the absence of reliable government welfare systems. And finally, CSGs played a very vital role in the expansion of the political space. Indeed, the activities of CSGs such as prodemocracy and human rights groups gained legitimacy among the Nigerian citizenry. They not only fought for the establishment of a Nigerian state based on accountability, transparency and democracy but also ensured the sustenance of the democratic process between 1999 and 2007. Some of the CSGs that played active role in the Nigerian democratization process between 1960 and 2007 include: Civil Liberties Organizations (CLO), Nigerian Labour Congress (NLC), Academic Staff Union of Universities (ASUU), Transparency in Nigeria (TIN), Committee for the Defence of Human Rights (CDHR), Nigeria Bar Association (NBA), National Democratic Coalition (NADECO), Campaign for Democracy (CD), Movement for the Advancement of Democracy (MAD) and United Action for Democracy (UAD). All these are CSGs from within Nigeria. However, there are those CSGs that operated from outside Nigeria, but with Nigerians in the Diaspora as its members. Some of these are: National Liberation Council (NALICON) and the United Democratic Front of Nigeria (UDFN) (Research Directorate, 1997). The primary function and importance of CSGs during this period was that it provided a platform for the citizens to express their interests, passions, preferences and ideas [25]. It further helped the citizens to exchange information, achieve collective goals, make demands on the state and hold the state officials accountable.

The CSGs that operated in Nigeria between 1960 and 2007 can be divided into five broad groups. It should be pointed out here that it was the kind of activities that each CSGs engaged in during the democratization process that determined the placement in a specific group. The five groups are: 
(i) Professional association, labour and students group

(ii) The human rights and pro-democracy group

(iii) Primordial group

(iv) The voluntary and mutual support group

(v) Business group

The first group describes entities that form traditional type of pressure group. Organizations that belong to this group have acted as the conscience of society. They have a long history of varying levels of confrontation with the state traversing the colonial and post-colonial periods in Nigeria's history. This group provided the intellectual aspect to the democratization process in Nigeria. Example of organizations that belong to this category include the NBA, NMA (Nigerian Medical Association), ASUU, NLC, NUJ and NANS. The core objective of this group was to mobilize the people against unpopular state policies that tended to result in socio-economic hardship. In the second category are those CSGs that emerged in response to the restricted and constricted political space created by military regimes in the 1980s and 1990s. This category was formed by individuals and concerned professionals that came together to harness resources and mobilize against the oppressions and repressions that inhered in military rule. They introduced such concepts as democracy, good governance, accountability and human rights into the democratization process in the 1980s and 1990s. Some of them include: CLO, CDHR, Constitutional Rights Project (CRP), League for Human Rights (LHR), Centre for Development Democracy (CDD) and Centre for Research and Documentation (CRD).

Primordial Groups, which is the third category are those based on ethnic, regional, religious and sectarian identities. Identities formed the basis on which these organizations are founded. Identity emphasized division and ethnic exclusivity. Majority of these kinds of CSGs were generic to the south-south and south-west geo-political zones of Nigeria. This was because of the premium the ethnic minorities in the region placed on identity. Environmental issues, such as the negative impacts of oil exploration on the communities in the zone further encouraged the proliferation of these types of CSGs. Some good examples are the OPC, the IYC and Movement for the Actualization of the Sovereign State of Biafra (MASSOB). In addition, faith-based CSGs fall within this category. The most prominent ones include the Christian Association of Nigeria (CAN) and Supreme Council for Islamic Affair in Nigeria (SCIAN). These two associations were particularly active during the military regimes of General Sani Abacha. They actively focused on issues of democracy, accountability, religious tolerance and transparency.

The fourth category refers to CSGs that existed within the organized business and private sector. They existed in the key sectors such as manufacturing and industry of the Nigerian economy. Two good examples are the Manufacturers Associations of Nigeria (MAN) and the Nigerian Chambers of Commerce and Industry (NCCI). In the final category are CSGs that were more active in rural areas. The primary concern of the CSGs in this category was the empowerment of their members [26]. The harsh economic conditions that prevailed during the military regimes of both Generals Babangida and Abacha encouraged the proliferation of this category of CSGs. These CSGs were normally galvanized into action by specific negative socio-economic policies of the state. Instead of being confrontational with the state, they channeled their energies toward meeting specific socioeconomic needs of their members. They are what one can call 'apolititical CSGs'.

\section{CSGs and the Democratization Process in Nigeria, 1967-1985}

The CSGs injected the conceptual mechanism into the democratization process in Nigeria. Such concepts as accountability, human rights, good governance, rule of law, government of national unity, sovereign national conference, democracy and transparency are some of the conceptual tools the CSGs used in the country's democratization process between 1967 and 2007. With the end of the civil war in 1970, military rule became firmly entrenched in Nigeria. Since the political elites 
had failed to create a functional and democratic Nigeria, it was generally assumed that the military institution had what it takes to put the country on a stable footing. Nigerians yearned for democratic and political stability and based on their actions during the civil war, the military was thought to be the best institution that can create a stable and functional Nigeria. This explains the passivity of the CSGs in Nigeria between 1967 and 1983.

However, when the Buhari/Idiagbon regime, 1983-1985 came up with draconian and repressive decrees, the CSGs mobilized and carried out a campaign of civil disobedience. This period, it must be noted, marks the beginning of active CSGs participation in Nigeria's democratization process. Some of the decrees passed by the junta include decree No. 2, which provided for the detention of people considered to be a security risk; decree No. 4, aimed at curtailing the freedom of the press and decree No. 1 which suspended the constitutional provision pertaining to personal liberty [27]. These decrees were meant to curtail the human rights of the citizens. CSGs such as the Nigeria Union of Journalist (NUJ), NBA, National Association of Nigerian Students (NANS), and ASUU made Nigeria virtually ungovernable for the state. The instability and insecurity created by the adversarial relationship between the state and the CSGs in the Nigerian polity led to a state of virtual anarchy in the country. This was one of the reasons the General Babangida administration gave for ousting General Buhari in August, 1985.

\section{CSGs and the Babangida Regime, 1985-1993}

CSGs injected such conceptual tools as democracy, human rights, and transparency into the democratization process during the Babangida administration. The CSGs were very active in Nigerian politics during the regime of Babangida. This was because of the annulment of the June 12, 1993 election. An important milestone was made in 1987 when the CLO was formed to challenge the administration's human rights record [28]. The CLO was ableto expose, in graphic details, with documented evidence, the various human-rights abuses of the administration and its parastatals. As mounting opposition against the administration grew, the FGN resorted to proscribing and banning CSGs and their activities. For example, the state dissolved NANS and NLC in 1986 and 1988, respectively [29].

The most contentious issues that rallied the CSGs against the administration were the transition program of the state and the annulment of the June 12, 1993 federal election. The FGN initially set October 1, 1990 as the transfer date to civilian rule, but, it later shifted the handover dates three times . From October 1, 1992 to January 2, 1993 and finally to August 27, 1993. For the conduct of the 1993 election itself, the FGN only recognized two state-sponsored political parties, the SDP and the NRC. At the end of the election, which the SDP presidential candidate, Chief Moshood Abiola, won, General Babangida annulled the election. This singular act galvanized and mobilized the CSGs against the administration. The tension and apprehension created by the civil disobedience of such CSGs as CD, NLC and MAD eventually forced Babandiga to step aside in 1993.

\section{CSGs and the Abacha Regime, 1993-1998}

CSGs injected such conceptual tools as democracy, rule of law, human rights and sovereign national conference into the democratization process during the General Sani Abacha regime. The Abacha administration was very hostile to any form of dissent and political opposition. The regime dismantled all the structures of transition to civil rule programs put in place by the preceding government. Abacha's regime was regarded as one of the most repressive in Nigeria's history. Many human rights activists and the political opposition were detained, driven underground or forced into involuntary exile abroad. For example, the Nobel laureate, Professor Wole Soyinka fled Nigeria during the Abacha regime. He became the arrowhead of the opposition in the diaspora against the Abacha regime. Together with some pro-democracy activists, Soyinka formed the NALICON and later the UDFN in 1995 that subsequently became the vanguard of the opposition against the Abacha regime in the diaspora. Three important issues galvanized and mobilized the CSGs against the Abacha administration. The first was the continued detention of the winner of the 
June 12, 1993 presidential election. The second was the hanging of the leader of the Movement of the Struggle for the Ogoni People (MOSOP), Ken Saro-Wiwa in 1995 [30]; and more finally, was the desire of General Sani Abacha to transmute into a civilian president. These three issues pitted the CSGs against the state. The CD, NADECO,NALICON and JACON were at the forefront of trying to actualize and restore the presidency to the winner of the 1993 federal election. By April, 1998, all the five political parties that were to take part in the federal election that would have ushered in the Fourth Republic adopted General Sani Abacha as their sole candidate. It was this development that Bola Ige described as five fingers of a leprous hand. This adoption further galvanized the CSGs against the Ababcha administration. They reasoned that unless the military was forced from power any discussion about respect for human rights, rule of law and democracy would be an exercise in futility. However, with the death of General Abacha in June, 1998, the CSGs pressured the new military administrator, General Abdulsalami Abubakar into carrying out a short transition to civilian rule program. Their activities and the pressures they exerted eventually culminated in the birth of the Fourth Republic in 1999.

\section{CSGs and General Abdulsalami Abubakar's Regime, 1998-1999}

During the short regime of General Abdulsalami Abubakar, the CSGs played a crucial role in 'coercing' the junta into relinquishing political power in 1999. Apart from the conceptual tools, such as democracy and transparency that the CSGs injected into the democratization process, they also acted as society's watchdog. When the state launched its short transition program in late 1998, the CSGs adopted a two-pronged strategy in helping the democratization process along. These were the radical and constructive approaches. The first approach eschewed dialoguing with the military on any platform. The core demand of the CSGs that embraced this approach was for the military to go back into the barrack and allow a SNC to create an enabling environment for a new democratic dispensation. The CSGs that embraced this approach formed JACON and were led by the legal luminary, Chief Gani Fawehinmi [31].

The second approach believed in dialogue and compromise. The CSGs that embraced this approach reasoned that Abdulsalami had demonstrated enough goodwill and sincerity of purpose to warrant an engagement with the CSGs. This second group formed the Transition Monitoring Group (TMG) and it was led by Clement Nwankwo. Indeed, the second group played an important role during the 1999 federal elections. They acted as election observers and monitors. Thus, the activities of the CSGs during the period complemented the efforts of the state in building a functional, viable and democratic Nigeria.

\section{CSGs During the Fourth Republic, 1999-2007}

The CSGs injected such conceptual tools as transparency, true federalism, accountability, rule of law, democracy, good governance, sovereign national conference and due process into the democratization process between 1999 and 2007. In December 2004, CSGs, especially Pro-National Conference (PRONACO) galvanized the Obasanjo administration into reviewing the 1999 Constitution of the Federal Republic of Nigeria [32]. This was done in order to force the FGN to find solutions to the important challenges of federalism, aggressive ethno-regionalism and distribution tearing at the fabric of the Nigerian state. Besides, Obasanjo's third-term agenda was another important issue that mobilized the CSGs against his administration. The 1999 Constitution only allowed for a two-term presidency. Obasanjo's second-term would end in 2007 and it was his desire to extend his presidency into a third-term that galvanized the CSGs against his administration. Some of the CSGs that actively opposed the third-term agenda include Transition Monitoring Group (TMG), Citizen's Forum for Constitutional Reform (CFCR), Electoral Reform Network (ERN) and the CD. They formed an association known as the Civil Society Coalition Against Third Term. Thus, it was as a result of the vigorous opposition of the CSGs that Obasanjo's third-term project was defeated. 
Moreover, the impact of the CSGs was felt more in the areas of corruption and accountability during Obasanjo's administration. Through investigative reporting on corruption, CSGs, especially through the electronic media, gave the needed exposure to executive and public office holder corruption. By so doing, the CSGs forced the FGN to investigate and prosecute those found wanting. Additionally, through collaboration with the anti-graft and other law enforcement agencies, CSGs made it possible for highly placed public officials to be prosecuted. Some of those that were prosecuted and publicly humiliated include: Tafa Balogun, the former inspector general of police; Patricia Etteh, former speaker, Federal House of Representative; Adolphus Wabara, former senate president; and Fabian Osuji, former Minister of Education.

\section{Conclusion}

As the analysis has shown, the CSGs played prominent role in Nigeria's democratization process between 1960 and 2007. The CSGs' impact was not just limited to the political sphere, but it extended to the social, religious and economic spheres. In the military era, the CSGs were a constant thorn in the sides of the successive military administrations. In the post-military era, the CSGs acted as the watchdog of the society. Due to the lack of a credible opposition party in the Nigerian political landscape, the CSGs took up the role and acquitted itself admirably. The use of the conceptual mechanism made it possible for the CSGs to inject such concepts as accountability, transparency, rule of law and democracy into the country's nation-building process. Thus, it will not be far-fetched to assert that without the crucial role played by the CSGs in the period up to 1999, the birth of the Fourth Republic would not have been possible.

\section{REFERENCES}

[1] B.G. Powell Jr. and E. Powell, Democratization: a briefing paper for AP comparative government and politics. Information on

http://apcentral.collegeboard.com/apc/public/repository/ap05_comp_govpol_demo_42252.pdf (2005) $1-2$

[2] A.J. Falode, The state and nation-building in Nigeria, 1967-2007: a historical analysis, unpublished thesis submitted in fulfilment of the requirement for the award of $\mathrm{PhD}$ in History and Strategic Studies, department of History and Strategic Studies, University of Lagos, Nigeria (2012) $1-7$.

[3] E.A. Owolabi, Corruption and financial crimes in Nigeria: genesis, trend and consequences. Information on

http://citeseerx.ist.psu.edu/viewdoc/download?doi=10.1.1.590.2899\&rep=rep1\&type=pdf. 10.

[4] J.A.A. Ayoade, The federal character principle and the search for national integration in: 'K. Amuwo et al. (Eds.), Federalism and Political Resturcturing, Spectrum Books Limited, Ibadan, 2000, pp. 177-188.

[5] G.F. Mbanefoh and F.O. Egwaikhide, Revenue allocation in Nigeria: derivation principle revisited in: K. Amuwo, A. Agbaje, G. Heraul and R. Suberu (Eds.), Federalism and Political Restructuring, Spectrum Books Limited, Ibadan, 2000, pp. 213-227.

[6] S. Iroanusi, Nigeria's Heads of State and Government, Sam Iroanusi Publications, Lagos, 1997, pp. 30-31.

[7] T. Forrest, Politics and Economic Development in Nigeria, Westview Press, Oxford, 1993, p. 48.

[8] A. Agbaje, Mobilizing for a New Political Culture In: Diamond et al. (eds.), Transition Without End. Ibadan: Vantage Publisher, 1997, pp. 147-148. 
[9] U. Essia and A. Yearoo, Strengthening civil society organizations/government partnership in Nigeria, International NGO Journal. 49 (2009) 368.

[10] L. Diamond, Nigeria: The uncivic society and descent into praetorianism in politics in: L. Diamond et al. (Ed.), Developing Countries: Comparing Experiences with Democracy, Lynne Rienner Publishers, Boulder, 1995, pp. 418-419.

[11] J. Keane, Despotism and democracy: the origins and development of the distinction between civil society and the state 1750-1850 in: J. Keane (Ed.) Civil Society and the State, Verso, New York, 1988, p. 3.

[12] ActionAid, Civil society in Nigeria; contributing to positive social Change, CIVICUS Civil Society Index: Nigeria (2007) 18.

[13] E. Osaghae, The role of civil society in consolidating democracy: an african comparative perspective. Africa Insight 27. 115 (1997) 15.

[14] B. Boutros-Ghali, An Agenda for Democratisation, Department of Public Information: United Nations, New York, 1996, p. 1.

[15] C. Welzel, Theories of democratization in: C.W. Haerpfer, P. Bernhagen, R.F. Inglehart and C. Welzel (Eds.) Democratization, Oxford University Press, Oxford 2009, p. 74.

[16] S.P. Huntington, The Third Wave: Democratization in the Late Twentieth Century. Norman: University of Oklahoma Press, Norman, 1991.

[17] O. Akinboye and O. Oloruntoba, Civil society organizations and transition politics in Nigeria: a retrospective analysis of the 2007 General Elections. Unpublished paper, University of Lagos, September 26-27 (2007) 5.

[18] B. Olukoshi, Associational life in: L. Diamond, A. KirkGreene and O. Oyediran (Eds.) Transition Without End, Vantage Publisher, Ibadan, 1997, pp. 451-452.

[19] T. Falola and A. Genova, Historical Dictionary of Nigeria, The Scarecrow Press, Inc., Maryland, 2009, pp. 241-242.

[20] A.S. Banks et al. (Eds.), Political Handbook of the World: 1997 CSA Publication Binghamton, NY, 1997, p. 626.

[21] W. Soyinka, You Must Set Forth at Dawn: A Memoir, Random House, New York, 2006.

[22] L. Ekeanyanwu et al., National integrity systems: country study report, Nigeria 2004, Transparency International. (2004) 71.

[23] L.O. Imade, Democratizing democracy in Nigeria: the role of civil society organizations. Information on www.africabib.org/htp.php?RID=P00026757 (2001).

[24] International Institute for Democracy and Electoral Assistance (IIDEA), Democracy in Nigeria: continuing dialogues for nationbuilding. Information on

http://www.afrimap.org/english/image/documents/file42285da1a15bd.pdf (2000).

[25] L. Roniger, The contemporary study of clientelism and changing nature of civil society in contemporary world in: L. Roniger and Ayse Gunes-Ayala (Eds.) Democracy, Clientelism and Civil Society, Lynne Rienners Publishers, Inc., Boulder, Co:, 1994.

[26] A. Adedeji and O. Otite, Introduction in: A. Adedeji and O. Otite (Eds.), Nigeria: Renewal from the Roots?, Zed Press, London, 2007, pp. 1-20.

[27] B. Olukoshi, Associational life in: L. Diamond, A. KirkGreene and O. Oyediran (Eds.) Transition Without End, Vantage Publisher, Ibadan, 1997, pp. 452-455.

[28] I. Chukwuma, Government-civil society partnership in Nigeria: problems and prospects. Information on http://cleen.org/Government-civil\%20society\%20partnership.pdf (2005). 
[29] T. Falola and M. Heaton, A History of Nigeria, Cambridge University Press, Cambridge, 2008, pp. 255.

[30] S. Osha, Ethics and revisionism in Nigerian governance, Quest: An African Journal of Philosophy. XVI 1-2 (2002) 88.

[31] K. Shettima and I. Chukwuma, Crime and human rights in Nigeria. http://www.ichrp.org/files/papers/24/114_Nigeria_Crime_and_Human_Rights_Shettima_Kole_ _Chukwuma_Innocent_2002.pdf (2002).

[32] M. Abutadu, Federalism political restructuring and the lingering national question, in: S. Adejumobi (Ed.), Governance and Politics in Post-Military Nigeria, Palgrave Macmillan, New York, 2010, p. 14. 